Brigádní generál Ing. Jaromír Zůna, MSc., Ph.D., pplk. Ing. Janka Kosecová

Pojmový aparát mírových operací a jejich vymezení v doktrinálních dokumentech Armády České republiky



Vojenské rozhledy, 2014, roč. 23 (55), č. 4, s. 109-123, ISSN 1210-3292 (tištěná verze), ISSN 2336-2995 (on line). Článek prošel recenzním řízením.

\title{
The Terminology of Peace Support Operations and Their Definition in Doctrinal Documents of the Czech Armed Forces
}

\section{Abstrakt:}

Přispěvek definuje konceptuální pojmy aparátu mírových operací. V článku je stručně vysvětlen vývoj a historie mírových operací, dále se zabývá nociální formou základnich termínů a rozčleněním operací NATO na podporu míru do šesti základnich typů. Samostatná část článku popisuje vymezeni mírových operaci v doktrinálnich dokumentech Armády České republiky.

Mírové operace jsou ve své podstatě dynamickou a náročnou činností. Vedle rozšiřování politických a vojenských ambici se v současném turbulentním světě zvyšuje i jejich intenzita a komplexnost. To je i di̊vod, proč je zapotrebi tuto problematiku neustále přibližovat $i$ široké veřejnosti z různých pohledů, což je hlavním posláním tohoto článku.

\section{Abstract:}

The aim of this article is to clarify the terminology of Peace Support Operations. This article briefly explains the evolution and history of peacekeeping operations, as well as the basic concepts and operations division of NATO Peace Support Operations. An important part of this article is the definition of Peacekeeping Operations in the doctrinal documents of the Czech Armed Forces.

Peace Support Operations are dynamic and challenging activities. The intensity and complexity of Peace Support Operations has been increasing. That is why their political and military ambitions have been increasing too. There is a reason why authors explain this issue for readers, which is the main goal of this article.

\section{Klíčová slova:}

Mírové operace, předcházení konfliktů, operace na udržování míru, operace na prosazování míru, vytváření míru, budování míru, humanitární operace, doktrína.

Key words:

Peace support operations, conflict prevention, peacekeeping, peace enforcement, peacemaking, peacebuilding, humanitarian operation, doctrine. 


\section{Úvod}

Některé mezinárodní organizace, mezi které patř́ i NATO, jsou pověřeny Radou bezpečnosti OSN (RB OSN) k udržování regionálního míru a ke kontrole plnění jejího rozhodnutí. Mírové operace na regionální úrovni jsou velmi užitečným nástrojem, který je uznáván Chartou OSN. Pomocí nich může účinně dohlížet RB OSN na aktuální situaci.

V období posledních dekád a zejména od roku 1990 jsme svědky trvalého rozšiřování obsahu pojmu mírová operace, který se postupně rozvinul do řady forem. Dnešní mírové operace se významně odlišují od operací OSN na udržování míru z období studené války. Změnila se celá jejich koncepce a staly se komplexní a vojensky náročnou činností.

Soudobé mírové operace zahrnují, vedle tradičních úkolů, i taková opatření, která podporují organizaci voleb, prosazování lidských práv, formování nových států a rozšiřování prostoru demokracie. V řadě př́padů lze dnes označit mezinárodní a nevládní organizace a vojenské síly vyslané do mírových operací za architekty nových společností.

Pouhé zastavení otevřených forem nepřátelství a vytvoření prostoru pro politický dialog již nedostačuje aktuálním potřebám mezinárodního společenství na zajištění dlouhodobého a udržitelného míru a stability v krizových oblastech. Takové změny v chápání bezpečnosti jsou nejvíce patrné v Evropě. Komplexní charakter dnešních krizí a spektrum diplomatických, ekonomických, vojenských a dalších nástrojů, které jsou používány k jejich řešení, vyžaduje více než v minulosti rychlou aplikaci nových poznatků nejen ve vojenské oblasti, ale i v rovině politického rozhodování.

\section{Výklad základních pojmů, historický vývoj a vymezení obsahu mírových operací}

Současné trendy směrují k takovému typu mírových operací, které ve své podstatě budou komplexní civilní operací s vojenským podpůrným prvkem. Tenhle typ operace již aplikuje OSN v podobě multidimenzionálních [1] mírových operací a integrovaných misí. Použití síly je zaměřeno především k obraně mise, jejího poslání a prosazení mandátu.

Mírové operace mohou být uskutečňovány jako operace OSN (UN Peacekeeping Operations), alianční (NATO Non-Article 5 - Crisis Response Operations, a v jejich rámci NATO Peace Support Operations), pod vedením regionálních organizací (např. EU Petersberg tasks) [2] a koaliční (US Stability Operations, a v jejich rámci Peace Operations).

V souvislosti s tím se plánování, příprava a provedení mírových operací uskutečňuje v odlišném doktrinálním a teoretickém rámci. Od rozpadu bipolárně rozděleného světa se mírové operace vyvinuly v komplexní a účinný nástroj při zajišt’ování míru a bezpečnosti ve světě s funkčně vymezeným politickým, právním a vojenským rámcem.

Úkoly ozbrojených sil jsou stanoveny v zákoně č. 219/1999 Sb., o ozbrojených silách ČR (OS ČR), a další úkoly vyplývají z členství v NATO a EU. OS ČR se primárně připravují na obranu území ČR. Mimo plnění jiných úkolů OS ČR se mohou zapojit do mezinárodních operací $\mathrm{k}$ ochraně bezpečnostních zájmů, zvládání krizí a mohou se podílet na prevenci konfliktů a poskytnutí pomoci jiným zemím při budování jejich schopností. Tyto operace budou mít vždy charakter operací na prosazování a udržování míru, humanitárních nebo záchranných misí. 


\subsection{Obsah základních pojmů}

Vývoj pojmového aparátu v oblasti mírových operací prochází rychlým vývojem. Ten je zaprríčiněn především množstvím mezinárodních aktérů, kteří do uvedené oblasti vstupují. Dále změnami v bezpečnostním prostředí, které vyvolávají potřebu vypracování nových koncepcí pro řešení krizí a ohrožení nového typu. V neposlední řadě konvergencí př́istupů mezinárodních organizací $\mathrm{k}$ otázkám bezpečnosti, vzájemnému přejímání koncepčních př́stupů, a tím i pojmového aparátu. Podstata jednotlivých organizací, politické motivy a z toho vyplývající formulace cílů pro řešení jednotlivých krizí, národní zájmy států a další okolnosti ale vedou $\mathrm{k}$ odlišnostem $\mathrm{v}$ definičním vymezení jednotlivých pojmů a funkcí mírových operací.

V současné době není $\mathrm{k}$ dispozici jednotná, koordinovaná a univerzálně přijatá terminologie a ani jednoznačné definice těchto termínů pro oblast mírových operací. Existuje řada koncepčních a teoretických přístupů národních, aliančních a mezinárodních a nevládních organizací. Přes existující rozdílnosti v koncepčních přístupech k mírovým operacím je však všeobecná shoda v chápání obsahu základních pojmů a typů mírových operací.

\subsubsection{Termín „mírová operace“ v prostředí OSN}

Termín mírová operace není přesně definován a jeho definice není ani v textu Charty OSN. Lze se přiklonit k definici termínu mírová operace tak, jak ji uvádí J. Zůna (2007): , V současné doběje použiván jako termín sloužicí k obecnému označeni širokého spektra civilnich a vojenských činností, které se uskutečnuji v rámci prevence vzniku a eliminace existujicich konflikti̊ (krizí). S tímto obsahem je termín použiván i v textech hlavnich bezpečnostnich dokumentů a ve vojenských doktrinách států."

Který $\mathrm{z}$ typů mírových operací bude použit a $\mathrm{v}$ jakém politickém rámci bude mírová operace eventuálně vedena, vychází z politického rozhodnutí, charakteru krize a aktuální situace $\mathrm{v}$ bezpečnostním prostředí. Termín mírová operace a postupně $\mathrm{i}$ jeho obsah byly ve skutečnosti převzaty z vojenské doktríny USA, která vždy nahlížela na operace na udržování a prosazování míru definované $\mathrm{v}$ Chartě OSN jako na součást širšího konceptu politických, diplomatických, ekonomických a vojenských činností, které označovala za mírové operace.

Mírové operace OSN zaznamenaly od svého vzniku v roce 1948 významný vývoj. Charta OSN rozlišuje dva základní typy operací. Operace podle kapitoly VI Charty operace na udržování míru (peacekeeping) a operace podle kapitoly VII Charty - operace na prosazování míru (peace enforcement).

Operace na udržování míru se uskutečňují pod mandátem OSN nebo regionální organizace, se souhlasem stran zúčastněných v konfliktu (krizi) a v souladu s principy činnosti OSN. Operace na udržování míru jsou obecným označením pro různé typy činností, které jsou zaměřeny na: prevenci vzniku a řešení konfliktů; prosazování práva a pořádku v krizových oblastech; humanitární činnosti; obnovu politických institucí a funkcí státu, které byly narušeny v důsledku krizové situace; a obnovu základních podmínek života obyvatelstva v krizových oblastech.

OSN považuje operace na udržování míru nejen za typ operace, ale i techniku (taktiku) provedení. Tyto operace jsou považovány za součást procesu politického řešení krizí. Politické a vojenské činnosti a cíle operace jsou transparentní, založené na politickém 
konsenzu stran s procesem politického urovnání konfliktu. Vojenský profil operací na udržení míru je nízký, zaměřený především na následující úkoly: dohled nad dodržováním smluv o př́měří; monitorování zón separace; dohled nad budováním opatření vzájemné důvěry; realizaci procesu odzbrojování a demobilizace dříve znepřátelených stran a další činnosti. Jde o operace dlouhodobé a jejich úspěšnost je závislá na úrovni spolupráce dříve zneprátelených stran.

Operace na prosazování míru se uskutečňují na základě mandátu OSN, který je formulován v souladu se zněním kapitoly VII Charty OSN. Jde o bojové operace zahrnující použití, nebo hrozbu použití, ozbrojených sil. Vzhledem k jejich vojenskému rozměru, organizační náročnosti a potřebě rozsáhlé mobilizace vojenských kapacit na jejich vedení OSN preferuje jako postup delegaci plánování, př́pravy a provedení těchto operací na kompetentní regionální organizace, stálé vojenské Aliance, nebo účelové koalice kombinované s rolí vedoucí země. Př́íkladem takto vedené operace na prosazování míru byla např́iklad operace Desert Storm (1991), [3] ve které byl použit model mnohonárodní koalice s rolí vedoucí země, dále mírová operace Implementation Force, označovaná zkratkou IFOR (1996), která byla vedena jako alianční operace s účastí partnerských zemí, nebo válka v Koreji (1950-1953), ve které působily síly OSN s USA v roli vedoucí země. [4]

\subsubsection{Termín „,mírová operace“ v prostředí NATO a v české terminologii}

V souladu s AAP-06 (2013) je v NATO zaveden termín „Peace Support Operation“, který je do českého jazyka v tomto standardizačním dokumentu přeložen jako „mírová operace“, ovšem do roku 2010 byl termín př̀kládán jako „operace na podporu míru“. Z čehož vychází určité terminologické nejasnosti při tvorbě českých zejména doktrinálních dokumenti̊. Český překlad definice dle AAP-06 je „,Operace, při kterých jsou nestranně použivány diplomatické, civilní a vojenské prostředky, zpravidla podle zásad a principů Charty OSN, za účelem obnovení nebo udržení míru. Tyto operace mohou zahrnovat predcházeni konfliktům, vytváření míru, prosazování míru, udržování míru, budování míru a humanitární operace. “

V současnosti je nyní zapotřebí akceptovat tenhle poměrně nejasný překlad termínu „Peace Support Operation“v české terminologii, i když ve stejném terminologickém slovníku slovenské verzi Slováci pořád používají překlad ,,operácia na podporu mieru“.

Výše pospaná situace s termínem Peace Support Operation se stejně vyvíjí dál, protože dle ratifikačního draftu STANAG [5] 2181 je termín mírová operace neboli operace na podporu míru (Peace Support Operation) nahrazen termínem Peace Support Effort. STANAG 2181 je přejímacím dokumentem pro Spojeneckou společnou doktrínu vojenského prispěni k zabezpečení míru AJP-3.4.1(A) a na základě Analýzy standardizačního dokumentu čj. 1-4/202014/DP-1970, který byl vypracován Centrem doktrín u VeV-VA, je navržen český překlad tohoto termínu ,podpora míru a mírové úsili“. Ovšem je zcela pravděpodobné, že překlad se bude ještě vyvíjet před jeho konečným schváleným a ukotvením ve Slovníku termínů a definic NATO AAP-06.

V tomto článku je také použit překlad termínu Peace Support Operations jako operace na podporu míru v NATO, pro lepší srozumitelnost.

Operace na podporu míru v NATO (PSO - Peace Support Operations) jsou koncepcí mírových operací vedených v aliančních podmínkách NATO. Pojetí operací NATO 
je jiné, než je tomu v př́ípadě operací OSN, kde základní členění a obsah mírových operací jsou definovány Chartou OSN.

Základní členění operací NATO je na operace podle čl. 5 Severoatlantické smlouvy - Operace kolektivní obrany a operace mimo čl. 5 Severoatlantické smlouvy - Operace na řešení krizí [MC 372/2 - Non Article 5 - Crisis Response Operations (CRO)]. Operace na podporu míru jsou ve struktuře operací NATO začleněny ve struktuře operací na řešení krizí (NATO CRO).

Operace NATO na řešení krizí nenabízí seznam možných operací na řešení krizí. V NATO jsou chápány jako operace podporující civilní mezinárodní a nevládní organizace při řešení krizí prostřednictvím realizace operací, jejichž možná škála zahrnuje od prosazování sankcí, embarga a hrozby silou, přes operace na podporu míru až k vojenským bojovým operacím. V rámci svých operací může NATO v CRO (Crisis Response Operations) plnit i řadu jiných úkolů, jako je odstraňování následků živelních pohrom, humanitární operace, evakuace a záchrana osob, prosazování embarg a sankcí, záchranné a vyhledávací operace.

Z uvedeného lze vyvodit závěr, že NATO směřuje k pružnému chápání CRO, kde skutečnost, že úkol není definován, neznamená, že se nemůže stát CRO a následně operací na podporu míru. Operace na podporu míru v NATO terminologii jsou však obvykle známé jako „mírové operace“ dle Slovníku termínu a definic NATO AAP-06 (2013), česká verze. Ovšem ve stejném terminologickém slovníku, slovenské verzi, je pořád používán překlad „operácia na podporu mieru“. Dle AAP-06 (2013) jsou mírové operace definované jako ,, operace, při kterých jsou nestranně použivány diplomatické, civilní a vojenské prostředky, zpravidla podle zásad a principů Charty OSN, za účelem obnovení nebo udržení míru“. Dle ratifikačního draftu STANAG, [5] 2181, je pojem mírová operace (Peace Support Operation) nahrazen termínem podpora míru a mírové úsilí (Peace Support Effort).

Operace na podporu míru rozlišují šest základních typů mírových operací (viz tab.), které se řídí souborem principů definovaných Aliancí.

Tab.: Operace na podporu míru

\begin{tabular}{|c|l|l|}
\hline P.č. & \multicolumn{1}{|c|}{ Anglický název } & \multicolumn{1}{c|}{ Český název } \\
\hline $\mathbf{1 .}$ & Conflict Prevention & předcházení konfliktů \\
\hline $\mathbf{2 .}$ & Peacekeeping & udržování míru \\
\hline $\mathbf{3}$. & Peace Enforcement & operace na prosazování míru \\
\hline $\mathbf{4}$. & Peacemaking & vytváření míru \\
\hline $\mathbf{5 .}$ & Peacebuilding & budování míru \\
\hline $\mathbf{6 .}$ & Humanitarian Operations & humanitární operace \\
\hline
\end{tabular}

Autor: Kosecová, 2014.

Operace na podporu míru jsou operace politické, realizované s využitím integrovaných vojenských struktur a vojenských schopností Aliance a partnerů. Aliance má schopnost vést operace podle kapitoly VI a VII Charty OSN.

Operace na podporu míru představují kvalitativní změnu a zcela nové pojetí mírových operací, které jsou značně odlišné od operací OSN. Představují novou filozofii, jiný způsob vojenského i politického myšlení, protože odlišná je i podstata organizace, 
která je realizuje. Rozdílnost mezi operacemi OSN a operacemi NATO na podporu míru je zřetelná, zejména pokud je nahlížena prostřednictvím principů, na kterých jsou tyto operace založeny.

Operace na podporu míru prošly rychlým vývojem a jsou v současné době relativně uceleným a široce rozpracovaným teoretickým východiskem, které koresponduje s aktuálním vývojem a vytváří předpoklady pro jednotný př́istup členských zemí Aliance a partnerských zemí k plánování, př́ípravě a provedení mírových operací. Operace na podporu míru jsou v současnosti nejbližším vyjádřením konsenzu, kterého bylo mezi členskými zeměmi Aliance a partnery dosaženo o podstatě a obsahu mírových operací.

Nespornou výhodou a základem úspěšnosti PSO (Peace Support Operations) je, že důsledně vycházejí ze základních rídících a plánovacích dokumentů NATO, jsou opřeny o existující integrované vojenské struktury a reálné bojové možnosti Aliance. Připravenost a interoperabilita partnerských zemí se silami Aliance je zabezpečována prostřednictvím programu Partnerství pro mír (PfP - Partnership for Peace).

Uvedené skutečnosti zajišt'ují funkčnost, efektivitu a kredit sil na podporu míru (PSF - Peace Support Force) vyčleněných k vedení operace na podporu míru. Operace na podporu míru se od roku 1996 postupně staly významnou součástí mírových operací a svým charakterem dokázaly vyplnit existující mezeru ve schopnostech OSN při realizaci vojensky náročných činností.

\subsection{Historický vývoj mírových operací}

Obsah Charty OSN původně řešil vojenské konflikty, které byly vedeny mezi jednotlivými státy. Konec druhé světové války byl mezníkem v charakteristice vojenských konfliktů. Po tomto období vznikly konflikty nového typu, takzvané asymetrické konflikty, jejichž řešení si vyžádalo vypracování nových př́stupů a teorií jak na národní úrovni, tak ze strany mezinárodních a nevládních organizací. Souběžně se vznikem nového typu vnitřního konfliktu bylo pro vývoj v bezpečnostním prostředí v uplynulých dvou desetiletích charakteristické rozšiřování prostorů nestability, postihující regiony nebo širší geografické oblasti, které dnes mohou zahrnovat i několik státních útvarů. Prostory dnešních krizí tak mohou mít zcela nesouvislý charakter a operace na řešení krizí, jejichž součástí jsou i mírové operace, mohou spočívat ve vedení simultánních, nezávislých a distribuovaných vojenských i nevojenských činností.

Vzhledem ke komplexnímu charakteru soudobých krizí, které mají rozměr bezpečnostní, humanitární, kulturní, sociální, ekonomický a další, není podstata dnešních krizí řešitelná ani unilaterálními přístupy ani nekritickým přeceňováním potenciálu vojenských nástrojů síly. Přestože krize nového typu intenzitou vojenských činností spadají do kategorie konfliktů nízké intenzity, jejich řešení vyžaduje strategické př́stupy a pohled na mírové uspořádání a zajištění udržitelného rozvoje, které následuje po ukončení krize. Ani nejbohatší země nejsou v soudobých podmínkách schopné samostatně soustředit úsilí a prostředky, které by dokázaly zajistit vybudování demokratických a prosperujících společností v zemích, které nemají tuto tradici a trpí rozsáhlým deficitem vědomostí.

Řešení spočívá v koordinovaném použití celého spektra diplomatických, ekonomických, vojenských a informačních nástrojů síly, kterými státy disponují, a bude se opírat o funkční mezinárodní bezpečnostní systém. 
Od počátku 90. let OSN ve spolupráci s dalšími mezinárodními organizacemi iniciovalo bezprecedentní aktivity směřující $\mathrm{k}$ ukončení válek a posílení stability a bezpečnosti ve světě a pracovalo ve větším rozměru, než bylo při založení této organizace předpokládáno. Širší aplikací kapitoly VIII Charty OSN, pojednávající o regionálních formách řešení krizí a konfliktů, byl vytvořen předpoklad pro plné zapojení regionálních organizací a formálních aliancí do akcí při zajištování míru a bezpečnosti ve světě.

Mírové operace v období studené války byly vojenskými operacemi. V uplynulých dvou desetiletích byl do obsahu mírových operací začleněn komplex nových činností a úkolů. Civilní úkoly, které dnes tvoří hlavní obsah mírových operací, zahrnují široké spektrum dlouhodobých programů politické, ekonomické a sociální obnovy země, budování státních institucí, obnovu zákonnosti a prosazování lidských práv a integraci nových společností do mezinárodních institucí.

Ve vojenské oblasti byly pasivní dohled, vytváření zón separace mezi znepřátelenými stranami a dohled na realizaci mírových smluv nahrazeny aktivními vojenskými činnostmi, které jsou na taktických stupních velení mnohdy totožné s bojovým použitím jednotek. Jde o vytvoření bezpečného prostředí v pravém smyslu tohoto pojmu.

\subsection{Reforma mírových operací OSN.}

V roce 2002 přijalo OSN rozhodnutí reformovat mírové operace pod svým vedením. Cílem bylo dosáhnout vyšší účinnosti působení mezinárodního společenství v krizových oblastech a zajistit rovnoměrnější sdílení odpovědnosti při zajištování míru a bezpečnosti ve světě. Reforma mírových operací OSN si kladla za cíl zcela přebudovat schopnosti mezinárodních organizací, které jsou nutné $\mathrm{k}$ jejich vedení.

Východiskem pro realizaci reformy byly strategické dokumenty, které na počátku 90. let položily teoretické základy pro mírové operace OSN po ukončení studené války. Především šlo o dokumenty An Agenda for Peace - Preventive diplomacy, Peacemaking and Peacekeeping (1992) a Supplement to An Agenda for Peace: Position Paper of the Secretary-General on the Occassion of the Fiftieth Anniversary of the United Nations (1995).

Dále byly využity zkušenosti získané OSN, EU, NATO a OBSE z vedení mírových operací a koncepce, které uvedené organizace vypracovaly. Výsledkem tvorby nové koncepce mírových operací byla zpráva The Brahimi Report: Report of the Panel on United Nations Peace Operations (2002), ve které bylo definováno 73 doporučení, na jejichž základě byl zahájen proces přebudování schopností, kapacit a způsobu vedení mírových operací pod vedením OSN a dalších mezinárodních organizací.

Reforma mírových operací OSN byla úspěšná a iniciovala řadu konkrétních opatření a dlouhodobých programů, které vedly ke zvýšení globálních kapacit pro vedení mírových operací. Vzhledem $\mathrm{k}$ intenzitě a rozsahu podpory, která byla poskytována ze strany nejvyspělejších zemí, provedlo OSN reformu svých schopností rychleji, než se předpokládalo. OSN v současné době disponuje funkčním pohotovostním systémem, systémem generace sil, pružným systémem logistického zabezpečení a udržitelnosti sil v mírové operaci s globálním dosahem, které v některých ohledech přesahují schopnosti regionálních organizací a vojenských aliancí. 


\subsection{Vymezení obsahu a účelu základních typů operací na podporu míru /mírových operací}

Operace na podporu míru zpravidla probíhají se souhlasem znepřátelených stran. Názornou představu, kdy tyto typy operací probíhají při a po konfliktu, poskytuje obr.

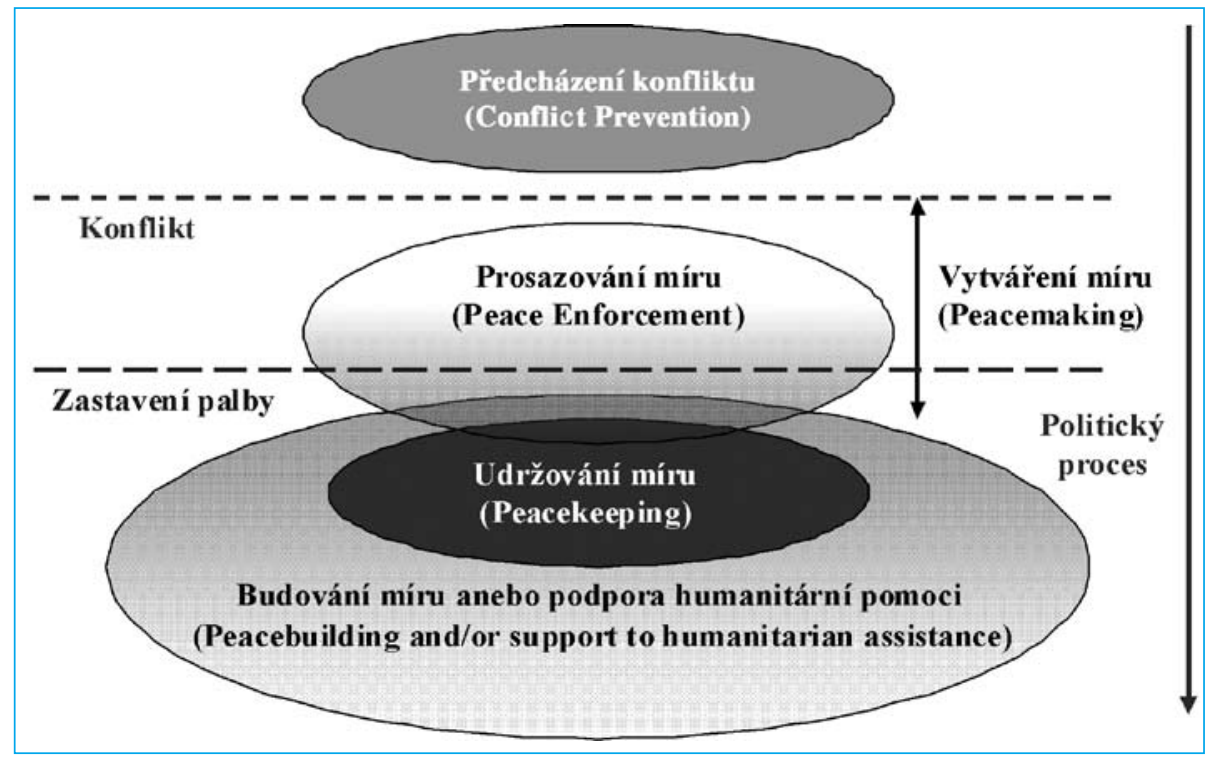

Zdroj: Upraveno z DAČR, 2013.

Obr.: Základní pojmový rámec operací na podporu míru.

\section{Operace na podporu míru nazývaných i mírové operace se člení na:}

- Předcházení konfliktům (Conflict Prevention) - soubor činností uskutečňovaných v souladu s kapitolou VI Charty OSN, zahrnujících činnosti od diplomatických iniciativ až po preventivní rozmístění sil s cílem zabránit eskalaci krize na úroveň ozbrojeného konfliktu.

V některých př́padech může situace v krizové oblasti vyžadovat preventivní rozmístění sil s mandátem a schopnostmi podle kapitoly VII Charty OSN k zabezpečení jejich odstrašující funkce. Vojenské činnosti v prevenci konfliktů mohou zahrnovat: diplomatické aktivity; aktivaci systému včasného varovaní o nastávající krizi; pozorování; monitorování; výcvik příslušníků místních ozbrojených a bezpečnostních složek; konzultace; programy směřující k reformě bezpečnostního sektoru dané země; inspekce; sankce; embarga; mise ke zjištění faktů a zhodnocení situace; preventivní rozmístění sil.

Preventivní rozmístění sil je jedním z nejsilnějších signálů o rozhodnosti angažovat se při řešení vznikající krize. Preventivní rozmístění sil může zahrnovat cvičení, přelety nad krizovými oblastmi, přesuny námořních sil do předsunutých prostorů, rozmístění pozemních sil a letectva v prostorech přilehlých ke krizové oblasti. Sankce a embarga jsou činnosti uskutečňované na základě rozhodnutí RB OSN. Dle AAP-06 (2013) je pojem předcházení konfliktům definován následovně: „,Mírová operace využivající 
vzájemně se doplñujících diplomatických, civilních a v prípadě nutnosti také vojenských prostředků pro sledování a odhalování př́čin konfliktu a pro přijetí včasných opatření k předejití vzniku, stupňování nebo obnovení nepřátelství. “

- Udržování míru (Peacekeeping) - operace uskutečňované v souladu s kapitolou VI Charty OSN za účelem monitorování, dohledu a asistence při realizaci mírových dohod k urovnání konfliktů (krizí) mezi státy nebo uvnitř státu. Operace na udržování míru se uskutečňují pod mandátem OSN nebo jiné mezinárodní organizace (EU, OBSE atd.), a se souhlasem všech hlavních stran zúčastněných v konfliktu.

Operace se skládají z civilních a vojenských komponentů. Z vojenského hlediska mírové síly úzce spolupracují s mezinárodními nevládními a vládními organizacemi při podpoře politického procesu směřuícího k udržování nebo dosažení trvalého míru. Mírové síly v těchto operacích zpravidla plní následující úkoly: separace znepřátelených stran; vytváření zón separace a demilitarizovaných zón; monitorování a dohled nad dodržováním mírové smlouvy; dohled nad odzbrojením a demobilizací znepřátelených stran; asistují při výměně teritorií; zajišt'ují bezpečné prostředí pro činnost mezinárodních a nevládních organizací; vyšetřují případy porušení prríměří, mírových smluv a dohod o zastavení palby; používají techniky vyjednávání a nevojenského řešení sporů.

Činnost mírových sil je nestranná a transparentní. Použití vojenské síly k prosazení mandátu je v operacích na udržování míru převážně omezeno na vlastní obranu příslušníků mírových sil. Širší použití vojenské síly se v těchto operacích uskutečňuje na základě sankcí RB OSN zpravidla za účelem stabilizace situace nebo prosazení dílčích ustanovení mandátu (např́iklad doprovod a ochrana konvojů s humanitární pomocí).

Dle AAP-06 (2013) je pojem udržování míru definován následovně: „,Mírová operace, která následuje po uzavřeni dohody nebo po zastavení palby, čímž bylo nastoleno př́znivé prostředís vysokou mírou shody a porozumění a s nízkou mírou hrozby narušeni tohoto stavu. Použití síly př́slušníky mírových jednotek se zpravidla omezuje na vlastni obranu."

- Operace na prosazování míru (Peace Enforcement) - jsou operace s mandátem podle kapitoly VII Charty OSN. Zahrnují hrozbu nebo přímé použití vojenských sil s cílem donutit zúčastněné strany ukončit ozbrojené akce a zahájit proces mírového řešení konfliktu. Cíle a politický proces řešení krize, které jsou obsaženy v mandátu OSN, odlišují operace na prosazování míru od války.

Operace na prosazování míru mohou zahrnovat bojové akce (operace) s cílem separovat a odzbrojit válčící strany. Bojové operace mohou být vedeny proti všem stranám konfliktu, nebo jedné z nich, pokud se odmítnou podřídit požadavku na zastavení palby. Operace na prosazování míru se uskutečňují v prrípadech, kdy diplomatické a politické prostředky pro urovnání konfliktu selhaly. Cílem vojenských činností je nastolit stav, kdy bude možné obnovit proces politického řešení konfliktu. Operace na prosazování míru mohou být rovněž provedeny za účelem prosazení mírového ujednání (mírové smlouvy), kterého již bylo na politické úrovni dosaženo, a jedna nebo více stran konfliktu neplní, nebo se očekává, že nebude plnit ustanovení mírových dohod.

Operace na prosazování míru jsou nutné i v př́ípadech, kdy je zřejmé, že mírová operace na udržování míru s mandátem podle kapitoly VI Charty OSN nebude postačovat k zastavení otevřených projevů neprrátelství, porušování lidských práv, nebo k dosažení požadovaného stavu - trvalého míru. 
Operace na prosazování míru jsou plánovány, připravovány a vedeny za podmínek existence př́mého ohrožení sil na podporu míru a reálného použití vojenských prostředků v souladu s mandátem pro operaci. Ve svých důsledcích může tento typ operace nabýt charakteru bojové operace a činnost sil je následně řízena v souladu s ustanovením polních řádů a předpisů pro bojové a operační použití vojsk.

Základním znakem, který odlišuje operace na prosazování míru od operací na udržování míru, je skutečnost, že mohou být provedeny bez souhlasu stran konfliktu s uskutečněním operace nebo jejím mandátem.

Mohou nastat i případy, kdy je souhlas s uskutečněním operace na prosazování míru vyjádřen na politické úrovni, ale na teritoriu konfliktu nemusí být ozbrojenými frakcemi respektován. Např́iklad zkušenosti NATO stále více potvrzují, že každá soudobá operace na podporu míru má i jisté znaky operací na prosazování míru, nebo je jako operace na prosazování míru vedena. $\mathrm{V}$ jejich průběhu musí být zajištěno velmi těsné provázání vojenských činností a politických cílů operace. Síly na podporu míru proto musí být vybaveny a organizovány nejen ke splnění krátkodobých vojenských úkolů, ale i k podpoře procesů na budování míru majících dlouhodobý charakter.

Dle AAP-06 (2013) jsou operace na prosazování míru definovány následovně: „Mírová operace vedená s cílem dodrženi zastavení palby nebo mírové dohody v těch prripadech, kdy míra souladu a porozuměni (zúčastněných stran) je nejistá a hrozba nedodržení je značná. Mírové síly musí být schopny použí přiměrenou donucovací sílu a musí nestranně aplikovat ustanovení o zastavení palby nebo mírové dohody. “

- Vytváření míru (Peacemaking) - zahrnuje diplomatické, politické, vojenské a jiné aktivity, které jsou zaměřené na ukončení otevřených projevů nepřátelství a nalezení politických prostř̌edků pro rychlé mírové řešení existujícího konfliktu. Opatření vytváření míru se realizují se souhlasem zúčastněných stran s procesem mírového uspořádání.

Souhlasu stran konfliktu může být dosaženo diplomatickým úsilím nebo tlakem mezinárodních organizací a jednotlivých států. Operace na vytváření míru jsou iniciovány po dosažení dohod o zastavení palby a ukončení otevřených projevů nepřátelství a jsou završovány podpisem dohod o příměří mezi dř́ve znepřátelenými stranami.

Vytváření míru je realizováno především diplomatickými prostředky, vyjednáváním, řešením sporů, sankcemi a dalšími činnostmi. Vojenské činnosti v operacích na vytváření míru směřují především k plnění podpůrných funkcí, kterými mohou být: separace stran; monitorování zastavení palby; plánování; hodnocení situace; př́íprava vojenských částí mírových smluv; přijímání preventivních opatření; eliminace hrozeb obnovení konfliktu; zajištění kontaktů mezi stranami konfliktu a realizace opatření na posilování vzájemné důvěry; prosazování pořádku a zákonnosti; formulace doporučení v oblasti bezpečnosti a výstavby ozbrojených sil; kontrolní a inspekční činnosti; přímé využití vojenských prostředků ke specifickým úkolům.

Dle AAP-06 (2013) je pojem vytváření míru definován následovně: „,Mírová operace vedená po vzniku konfliktu s cílem dosáhnout př́měří nebo mírového urovnání, $k$ čemuž je využiváno predevším diplomatických aktivit, které mohou být v připadě nutnosti podpořeny př́mým nebo nepř́mým použitím vojenských prostředkü. "

- Budování míru (Peacebuilding) - zahrnuje soubor činností směřujících do politické, sociální a vojenské oblasti k posílení politických přístupů při řešení příčin konfliktu. Operace (procesy) budování míru jsou zahajovány po ukončení ozbrojeného konfliktu. Jejich účelem je zabránit obnovení konfliktu v jakékoliv podobě. To zahrnuje 
mechanismy k identifikaci a podpoře struktur usilujících o konsolidaci situace, zajištění míru a sociální a ekonomickou obnovu země. Především ale jde o obnovu vzájemné důvěry mezi stranami konfliktu.

Jedním z hlavních úkolů je zajistit bezpečnostní garance obyvatelstvu, vyřešit situaci uprchlíků, bezdomovců a částí obyvatelstva, které nejvíce utrpěly vojenským konfliktem. Budování míru vyžaduje široké zapojení mezinárodních nevládních a humanitárních organizací do procesu obnovy a generaci zdrojů, které jsou nezbytné k podpoře dlouhodobých politických, sociálních a ekonomických procesů. Hlavní úsilí v tomto procesu je zaměřeno na ekonomickou obnovu a rekonstrukci infrastruktury, obnovu státních a občanských institucí a struktur, prosazování zákonnosti a pořádku, obnovu zdravotnictví a vzdělávacího systému.

Vojenské úkoly při budování míru směřují k dosažení hlavního cíle, kterým je demobilizace vojenských sil stran konfliktu a v součinnosti s mezinárodními organizacemi zpětná integrace jejich př́islušníků do společnosti. Specifické vojenské úkoly mírových sil mohou zahrnovat: udržování vojensky bezpečného prostředí; výcvik a podporu reformy místních ozbrojených sil; studium příslušníků místních ozbrojených sil v kurzech a na vojenských školách v zahraničí; podporu projektů obnovy a rekonstrukce země; podporu přípravy voleb; podporu mezinárodních a nevládních organizací při provádění humanitárních činností. Vojenské činnosti jsou transparentní a široce prezentované, zdůrazňující pozitivní dopad prrítomnosti mírových sil na bezpečnost obyvatelstva a obnovu mírového života.

Dle AAP-06 (2013) je pojem budování míru definován následovně: „, Mírová operace pro řešení základnich príčin konfliktu a pro dlouhodobé zabezpečení potřeb obyvatelstva, která využivá vzájemně se doplňujici diplomatické, civilní a v prípadě nutnosti vojenské prostředky. Tato mírová operace vyžaduje závazné a dlouhodobé vynakládáni úsilí a může probihat souběžně s jinými typy mírových operací. “”

- Humanitární operace (Humanitarian Operations) - v terminologii mezinárodních nevládních a humanitárních organizací se uvádí pro tuto činnost pojem humanitární akce. Jak již bylo uvedeno, mírové operace probíhají zpravidla v kombinaci jejich základních typů. Humanitární operace jsou téměř vždy součástí jakékoliv mírové operace, bez ohledu na formu a rozsah poskytované humanitární pomoci.

Humanitární pomoc je poskytována $\mathrm{v}$ souladu s principy humanitární pomoci a je nezávislá na činnosti mírových sil nebo ozbrojených složek dříve znepřátelených stran. Humanitární akce zpravidla zahrnují: poskytování potravin, lékařské pomoci, zdravotnického personálu a dalšího nutného materiálu a pomoci k ochraně života a zdraví postižené populace; výstavbu zdravotnických zařizení, uprchlických táborů, distribučních center, škol a institucí; evakuaci obyvatelstva, především žen a dětí, z rizikových oblastí; obnovu základní infrastruktury a budování systémů na podporu života, jako jsou vodovody, kanalizační systém, sklady potravin, střediska pro vakcinaci obyvatelstva, zařízení pro výrobu elektrické energie, organizace pohřební služby a další.

Hlavním úkolem mírových sil v humanitárních operacích je ochrana humanitárních pracovníků, humanitární pomoci a zařízení humanitárních organizací. Dle AAP-06 (2013) jsou humanitární operace definovány následovně: ,, Operace speciálně zaměřená na zmírněni lidského utrpení v oblasti, kde civilní představitelé zpravidla odpovědní za tuto činnost nejsou schopni nebo nechtěji odpovídajícím způsobem zabezpečit základní životni potřeby obyvatelstva. " 


\title{
2. Vymezení mírových operací v doktrinálních dokumentech Armády České republiky
}

\author{
Jednou zasetá doktrína zapouští kořeny hluboko \\ a respekt k minulosti nás všechny svazuje.
}

Harwey

Členění mírových operací do jednotlivých typů zohledňuje především politická hlediska. Struktura a obsah doktrinálních dokumentů v AČR naproti tomu vychází z aktuální potřeby řešit úkoly související se zajištěním interoperability v rámci NATO, podporovat transformaci na profesionální ozbrojené síly a působení jednotek AČR v zahraničních operacích. Proces transformace AČR je dále komplikován rychlým postupem vnitřní transformace NATO, které je dnes zcela jinou vojenskou aliancí, než jakou bylo při našem vstupu. $V$ prípadě NATO, je budoucí směřování aliance, výstavba schopností a rozvoj vojenské teorie ve vleku praxe soudobých operací. Pro AČR, jejíž doktrinální systém je převážně založen na hierarchii a obsahu doktrinálního systému v NATO, to vyvolává potřebu trvalých korekcí.

V roce 2012 byla vydaná Obranná strategie $\check{C} R$, která představuje záměr vlády ČR k zajištění obrany státu a která je postavena na třech hlavních pilirirích - zodpovědném přístupu státu, moderních a akceschopných ozbrojených silách a uvědomělých občanech. Dokument shrnuje hlavní úkoly českých ozbrojených sil a aktualizuje politickovojenské ambice ČR.

Ambice nasazovat české vojáky do zahraničních operací, mimo článek 5 Severoatlantické smlouvy, byla změněna a v současnosti odráží reálné schopnosti naši armády. Zatímco dosud ČR deklarovala schopnost vyslat kamkoliv do zahraničí brigádní úkolové uskupení o síle několika tisíc osob, nyní jsme připraveni takovou jednotku poskytnout pouze $\mathrm{v}$ př́ípadě kolektivní obrany v rámci NATO. Na tento dokument a další základní strategické dokumenty ČR jako je Bezpečnostni strategie ČR (2011), Bílá kniha o obraně (2011) a Dlouhodobá vize rezortu MO (2008) pak navazuje Doktrína AČR.

Doktrína AČR (2013) v kapitole 5 Vojenské operace a jejich vedení, vymezuje tyto operace jako „operace ve shoděs mezinárodním zmocněním, které spojuji diplomatické, ekonomické a vojenské prostředky, aby nestranně podpořily strategii obnovy a udrženi miru “. Určitým nedostatkem je ne zcela adekvátní translace některých pojmů z anglického jazyka do češtiny $v$ podkapitole 5.15 Operace na podporu míru. V této části by se měla dodržovat terminologie, která je uváděná ve standardizovaném dokumentu NATO-AAP-06.

Souhrn pravidel, zásad a principů pro působení AČR v mírových operacích řeší Doktrína AČR v mnohonárodních operacích (2008). Text doktríny vychází z politických

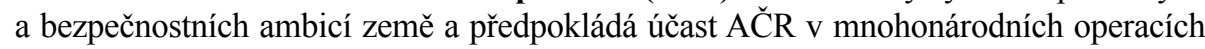
pod velením NATO, EU nebo OSN. Obsah doktríny se vztahuje především na prostředí NATO. Doktrína AČR v mnohonárodnich operacich (2008) v čl. 0105 vymezuje mírovou operaci následovně: ,, Mezinárodni společenství může reagovat na krizové situace ve světě tím, že rozvine v krizových zónách své silly a prostředky, které mají radu funkcí. Taková akce se obvykle označuje jako mírová operace a je vedena pod mandátem OSN. “

Uvedené pojetí mírových operací koresponduje s př́stupy EU k operacím evropské bezpečnostní a obranné politiky (EBOP), kdy EU deklaruje neoddělitelnost svých 
přístupů k řešení krizí od systému OSN. Rovněž tak jsou v bezpečnostních dokumentech EU definovány hrozby, nikoliv typy operací k jejich eliminaci. Volba preferovaného způsobu řešení krize bude ze strany EU vycházet z celkového posouzení konkrétní bezpečnostní situace a charakteru dané krize.

Mírovou operací tak může být jakýkoliv způsob řešení krize, který bude politicky za mírovou operaci označen a vyhoví základnímu požadavku na legitimní mandát OSN. NATO operace na podporu míru jsou v doktríně považovány za základní koncepci mírových operací pro AČR. Z doktrinálních dokumentů AČR lze zřetelně vyvodit směřování k univerzální aplikaci pojmu „operace“ pro všechny způsoby řešení krizí za použití vojenských sil a prostředků.

Operace NATO na podporu míru jsou proto $\mathrm{v}$ doktríně řešeny pouze $\mathrm{z}$ pohledu objasnění jejich principů a vymezení obsahu základních typů operací na podporu míru. Východiska pro plánování, přípravu a vedení mírových operací jsou založena na všeobecných prístupech $\mathrm{k}$ operacím.

Taktickým manuálem AČR pro činnost jednotek vyslaných do mírových operací je publikace Taktika spojeneckých mírových operací Pub-100-30-31 (2007), která je vypracována podle zásad NATO publikace Mírové operace-způsoby a postupy-Peace Support Operations, Techniques and Procedures (ATP-3.4.1.1.). Vzhledem k tomu, že tento STANAG 2496 byl zrušen dnem 24. září 2010, je nutné tuto vojenskou publikaci aktualizovat.

V současnosti je Česká republika připravena přistoupit k nové edici STANAG 2181, který přjímá Spojeneckou společnou doktrínu vojenského prispěni k zabezpečení míru - Allied Joint Doctrine for the Military Contribution to Peace Support, AJP-3.4.1 (A), kde pojem mírová operace (Peace Support Operation) je nahrazen termínem podpora míru a mírové úsilí (Peace Support Effort).

Tento dokument doplňuje, upřesňuje a rozpracovává na dané podmínky standardizační požadavky a postupy stanovené např́ič spektrem dalších spojeneckých doktrín jako je Spojenecká společná doktrina - Allied Joint Doctrine, AJP-01 (D); Spojenecká společná doktrína vedení operací-Allied Joint Doctrine for the Conduct of Operations (AJP-3(B); Spojenecká společná doktrína plánování na operační úrovni-Allied Joint Doctrine for Operational-level Planning, AJP-5; Spojenecká společná doktrína operací $k$ rešení krizových situací mimo článek 5 -Allied Joint Doctrine for Non-Article 5 Crisis Response Operations, AJP-3.4 (A) a Spojenecká společná doktrína civilně-vojenské spolupráce - Allied Joint Doctrine for Civil-Military Cooperation, AJP-3.4.9 (A).

AJP-3.4.1(A) poskytuje velitelům na strategické a operační úrovni potřebný rozhled a návod při plánování operací na podporu míru.

V návaznosti na finální draft Spojenecké společné doktriny vojenského přispěni k zabezpečeni míru AJP-3.4.1(A) po jeho vyhlášení bude nutné provést aktualizaci Pub 100-30-01 a zrušit definici ,mírové operace“ a zpracovat definici nově zavedeného termínu podpora míru a mírové úsilí ve Slovníku termínů a definic NATO AAP-06. V dalších doktrinálních dokumentech jako jsou Doktrína $A \check{C} R$ (2013); Doktrína $A \check{C} R$ $v$ mnohonárodnich operacich (2008), Pub-31-10-01 Pozemni sily v operacích (2011), a Pub-30-33-01 Použití vzdušných sil AČR v operacích (2008), není zavedení nového termínu v rozporu se stávající terminologii daných dokumentů.

V roce 2014 byla vydána vojenská publikace Zkušenosti jednotek AČR z operace ISAF. Jednotky AČR působí v zahraničních operacích déle než dvacet let a tato publikace 
je první ucelený dokument zevšeobecňující poznatky a zkušenosti z nasazení našich jednotek.

Vzhledem k tomu, že rozvoj doktrinální soustavy AČR se opírá spíše o formální řízení, které se orientuje na produkci vojenských publikací a předpisů, namísto rozvoje teorie pro použití sil, bude zapotřebí tento přístup změnit. Kapacity odborných pracovišt' jsou velmi omezené a navíc rozložené do řady institucí, které nejsou vázány ke vzájemné součinnosti. V doktrinální oblasti bude potřebné v širší míre aplikovat východiska a koncepce, které vznikají v prostředí OSN, EU, OBSE, případně dalších mezinárodních organizací.

\section{Závěr}

Vzhledem k celosvětovému vývoji bezpečnostního prostředí a z toho vyplývajících požadavků na mírové operace, dochází ke změně podstaty mírových operací tak, jak je známe z minulosti, k budoucím multidimenzionálním mírovým operacím.

Přes mimořádnou četnost publikovaných prací byla v minulosti věnována vypracování strategie a teorie mírových operací a humanitárních intervencí jen velmi malá pozornost. Neustálé změny, nové hrozby a rizika, rozvoj operačního umění, nové technologie i zkušenosti vyžadují neustálou a průběžnou aktualizaci a revizi veškerých doktrín. Při tvorbě doktrín je důležitý aspekt vzájemné spolupráce, zvláště při tvorbě a použivání jednotné terminologie a nociálního (pojmového) aparátu v oblasti řešení problematiky mírových operací. Oblast doktrinální v souvislosti s expanzí mandátů mírových operací OSN musí být zaměřena na dosažení vyšší kvality doktrinálních dokumentů, jasnosti úkolů, postupů, sběru a vyhodnocování zkušeností z operací.

\section{Poznámky:}

[1] Multidimenzionální př́stupy v podobě mírových operací zahrnují nástroje politické, ekonomické, sociální, vojenské, informační, humanitární a další, které umožňují realizaci dlouhodobých stabilizačních a rekonstrukčních činností.

[2] Petersbergské úkoly EU (Eropean Union Petersberg Tasks) jsou humanitární a záchranné akce, akce k udržení míru, akce bojových jednotek v krizových situacích, včetně prosazování míru.

[3] Desert Storm (operace Pouštní bouře), která je známá pod názvem válka v zálivu, byla konfliktem mezi Irákem a koalicí 28 států, které dostaly mandát od OSN mandát za účelem vyhnání agresora z Kuvajtu. IFOR, Implementation Force, byla mezinárodní vojenská mise pod vedením NATO v Bosně a Hercegovině, 1995-1996, na základě souhlasu Rady bezpečnosti OSN. Politickým rozhodnutím na misi IFOR navázala stabilizační mise SFOR, taktéž pod patronací NATO. Kódové označení mise bylo Operation Joint Endeavour a do operace se zapojilo téměř 60000 vojáků z řad států NATO i ze států mimo tuto organizaci. SFOR, Stabilisation Force, byla mezinárodní mírová mise pod patronací vojenské organizace NATO, 1996-2004, na území Bosny a Hercegoviny, která měla stabilizovat bezpečnost v oblasti a přispět k ustálení poměrů a rozvoji regionu. Skládala se ze dvou částí (Operation Joint Guard a Operation Joint Forge), které na sebe navazovaly a které pokračovaly v práci mise IFOR.

[4] Mnohonárodní vojenské operace, kterých se kontingent AČR může zúčastnit, lze obecně rozdělit do dvou základních skupin. První skupinu tvoří operace kolektivní obrany členských zemí NATO podle čl. 5 Severoatlantické smlouvy. Do druhé skupiny spadají operace mimo čl. 5 Severoatlantické smlouvy a obdobné operace na podporu míru vedené OSN nebo EU.

[5] STANAG - Standardizační dohoda je standardizačním dokumentem NATO, kterým se stvrzuje dohoda členských států o zavedení standardu, a to jako celku nebo jeho části tak, aby byl naplněn požadavek interoperability. 


\section{Použitá literatura:}

ALTENBURG, G. Training and Education - Aiming Towards Enhanced Interoperability in Peacekeeping. In NATO-Russia Council Working Group on Peacekeeping Seminar, 24-26 September 2003, Berlin.

GHALI, B. B. An Agenda for Peace-Preventive diplomacy, peacemaking and peacekeeping. United Nations: Report of the Secretary General, A/47/277-S/241111, 1992.

HAINE, Jean-Yves. Force Structures. Institute of Security Studies, Brussels, NATO Fact Sheet: NATO in Afghanistan, 2003.

HODGE C. C. Woodrow Wilson in Our Time: NATO's Goals in Kosovo. Parameters, US Army War College Quarterly, vol. XXXI, No.1, Spring 2001 Carlisle, s. 125-136.

SWEBERG, M. Challenges to Peacekeeping: Preparedness into the 21st century. In NATO-Russia Council Working Group on Peacekeeping Seminar, 24-26 September 2003, Berlin.

ZŮNA, Jaromír. NATO operace na podporu míru. Brno: Vojenská akademie, 2002, $127 \mathrm{~s}$. ISBN 80-859-6037-0.

ZŮNA, Jaromír. Mírové operace. Vojenské rozhledy, 2007, roč. 16 (48), č. 2, s. 41-50, ISSN 1210-3292 (tištěná verze), ISSN 2336-2995 (on line), dostupné z www.vojenskerozhledy.cz.

ZŮNA, Jaromír. Nové jevy v aliančním zabezpečeni obrany: sborník z 3. ročníku doktorandské konference: 18. dubna 2007, Brno. Vyd. 1. Editor Tomáš Hanák, Miroslav Ovesný. Brno: Univerzita obrany, 2007, 223 s. ISBN 978-80-7231-267-2.

ZU゚NA, Jaromír. Vliv změn v bezpečnostním prostředi na budouci použití jednotek AČR v mirových operacich. Dizertační práce, UO/FEM, Brno 2010.

AAP-06, Slovník termínů a definic NATO (anglicky a francouzsky). Praha: Úřad pro obrannou standardizaci katalogizaci a státní ověřování jakosti, odbor obranné standardizace, 2013.

AJP-3.4.1, Mírové operace (Peace Support Operations). NATO unclassified publication. NATO Military Agency for Standardization (MAS), JULY 2001.

AJP-3.4.1(A), Spojenecká společná doktrína vojenského přispění k zabezpečení míru (Allied Joint Doctrine for the Military Contribution to Peace Support). Final draft. National Standardization Agency (NSA), Edition A Version 1, 2014.

Doktrína Armády České republiky v mnohonárodních operacích. 1. vyd. Vojenská publikace. Vyškov: Správa doktrín ŘeVD VeV-VA, 2008., 143 s.

Doktrína Armády České republiky. 3. vyd. Praha: Ministerstvo obrany České republiky - Vojenský historický ústav Praha pro Centrum doktrín VeV-VA Vyškov, 2013, 156 s. ISBN 978-80-7278-619-0.

Obranná strategie České republiky. Praha: MO ČR [online], 2012 [cit. 2014-09-16]. Dostupné z http:// www.mocr.army.cz/images/id_40001_50000/46088/STRATEGIE_ce.pdf.

Pub-30-00-01. Zkušenosti jednotek AČR z operace ISAF. Vyškov: Institut rozvoje a doktrín VeV-VA, 2014.

The Brahimi Report: Report of the Panel on United Nations Peace Operations. United Nations, 2002, $\mathrm{A} / 55 / 305-\mathrm{S} / 2000 / 809$.

The Way Ahead-Relevant \& Ready. US Army, MoD USA, 2004.

V Alianci, přestože samožrejmě zdůrazňujeme, že Aliance je ve svých názorech jednotná, a navenek tomu tak je, v průběhu dosahování těch jednotných stanovisek je mnoho rozdílných pohledů na věc. A to se v dnešní době týká nejenom např. vztahu k Rusku a Ukrajině, to se týká i vztahu k řešení problému Islámského státu, týká se to i různých priorit členů Aliance nebo skupin členů Aliance, protože je jasné, že jinak vnímají svoje ohrožení státy na jižním křídle Aliance, které v současné době řeší především problém migrace, jinak ho vnímají státy přímo sousedící s Ruskem, jinak ho vnímají státy skandinávské. Rozdílné pohledy se musí v rámci jednotného stanoviska nějakým způsobem urovnat, vydiskutovat a probrat.

\section{Armádní generál Ing. Petr Pavel, M.A., náčelník Generálního štábu AČR. Setkání s hosty, kteří mají co říct, ČRo 2, 4. listopadu 2014. Dostupné na http://www.rozhlas.cz/dvojka/jejakaje/_zprava/1416408.}

